\title{
\begin{tabular}{ll}
\hline 薬 & 物 \\
\hline
\end{tabular} \\ 慢性扁桃炎に対する CAM 少量療法の臨床効果
}

\author{
三沢 逸人・岩垣 俊憲

\section{Clinical Effects of Low-dose Clarithromycin (CAM) Therapy for Chronic Tonsillitis}

\author{
Hayato Misawa and Toshinori Iwagaki \\ (Inazawa City Hospital)
}

\begin{abstract}
This study was carried out to determine the clinical effects of low-dose clarithromycin (CAM) therapy for the treatment of chronic tonsillitis. Forty-two patients were assigned randomly to two groups : $200 \mathrm{mg}$ of CAM per day (test group) and $400 \mathrm{mg}$ per day (control group) for 4 to 8 weeks. The final overall effectiveness rates inclusive of excellent or good efficacy were $64 \%$ for the test group, and $55 \%$ for the control group, respectively. No statistical differences were noted in terms of subjective or objective efficacy between two groups. No side effects were observed in the control group, whereas mild upset stomach appeared in one case in the test group. Low-dose application of CAM was thus proved to be as effective as standard application.

It was speculated that the efficacy of low-dose CAM therapy is mainly attributable to the immunomodulatory effects of 14-membered macrolides. These results suggested that low-dose administration of CAM can be useful for the treatment of chronic tonsillitis.
\end{abstract}

Key words : clarithromycin, low-dose administration, chronic tonsillitis, immunomodulatory effect

はじめに

近年，びまん性汎細気管支炎に対する14員環マクロラ イド系抗生物質の少量長期投与療法1) 4) の臨床効果につ いては確立された感がある。さらにその有用性は広がり， 今日では14員環マクロライドは, 慢性副鼻腔炎5) 8), 出性中耳炎9) 11), 悪性腫瘍12) など新領域の疾患に対し て臨床応用され, 理論構築が臨床の後追いする形で基礎 研究が進んでいる.それらの治療概念には14員環マク口 ライドの持つ抗菌力以外の作用, 寸なわち抗炎症作用, 免疫調節作用, 気道粘膜細胞に対する作用, 細菌産生物 質に対する作用などが根底にある。

このような背景を踏まえてわれわれは, 危疫臟器であ
ると同時に感染臓器にもなりらる口蓋扁桃においても, マクロライドがその炎症治瘉機転に何らかの好影響を与 えるのではないかと考壳た。

クラリスロマイシン (CAM) はェリスロマイシンの誘 導体で, エリスロマイシンより胃酸に安定で, 組織移行 性の高い14員環マクロライド系抗生物質であり，上記の 免疫調節能をはじめ種々の抗炎症作用, その他多くの薬 理作用をもつ薬剤である1314).

CAM の少量長期投与の薬効についてはびをん性汎細 気管支炎3) や慢性副鼻腔炎78) を中心に研究が進んでい るが，慢性扁桃炎に招いては CAM の少量長期投与の効 果についてのまとまった報告はなく，CAM が口蓋扁桃 
の慢性炎症に対し抗菌力以外にどんな薬理作用を示すの かも未知の段階である.そこでわれわれは慢性扁桃炎に 対してCAM を通常量(対照群)と $1 / 2$ 量(試験群)の 2 群 に分けて投与することによって, それらの臨床効果を比 較検討した。

\section{対象之方法}

対象は咽喉頭異常感を主訴に当科を受診し, 扁桃に膿 栓の付着が見られた，次の条件を満たす成人の慢性扁桃 炎症例とした(表 1).

$1)$ 年齢20歳以上, 2 ) 本試験前 4 週間以上未治療， 3 ) 妊娠や授乳の可能性のないこと, 4$)$ 糖尿病, 肝臓病, 腎蔵病などの合併症を有さないこと，5)本試験に影響 のある薬剤を服用していないこと，6)マクロライドア レルギーの既往のないこと， 7 ) 習慣性扁桃炎の既往の ないこと，8)精神障害その他で, 主治医が不適当と認 めた患者は除外する.

薬剤は原則として単独投与とし，薬剤投与量としては 試験群 $(1 / 2$ 群) としてクラリスロマイシン(CAM) 1 日
$200 \mathrm{mg}$, 対照群(通常群) としてCAM 1 日 $400 \mathrm{mg}$ の 2 群に無作為に分けて, いずれも分 2 で投与した. 両群の 薬剤投与期間は原則として $4 \sim 8$ 週間, 最短でも 2 週間 とした。

CAM 投与前および，陰窩内に膿栓を認めた場合は投 与 2 週後执よび終了時に細菌検查を可能な限り施行した. 投与期間中は手術, 高周波電気凝固治療, 陰窩洗浄は一 切行なわず，ネブライザーなどの局所治療も患者の希望 がない限り併用しなかった。

薬剤投与前後で自覚症状と他覚所見を別々に比較評価 し, 両者の改善度をもって総合判定した. 自覚症状の評 価項目としては咽喉頭異常感, 他覚的所見の評価項目と しては扁桃発赤, 陰窩内膿栓とし, 各々を高度 $(\mathrm{H})$, 中 等度 $(H)$, 軽度 $(+)$, ごく軽度 $( \pm)$, なし $(-)$ の 5 段階 にて評価した. 自覚症状としての咽喉頭異常感は小池 ら15) のスコア 7 点以上, 5 点以上, 3 点以上, 2 点以 上を各々高度, 中等度, 軽度, ごく軽度とした. 他覚所 見としての扁桃発赤は, 佐々木ら ${ }^{16)}$ の基準に準じて高 度, 中等度, 軽度, ごく軽度, なしの 5 段階, 陰窩内膿

表 1 対象および方法

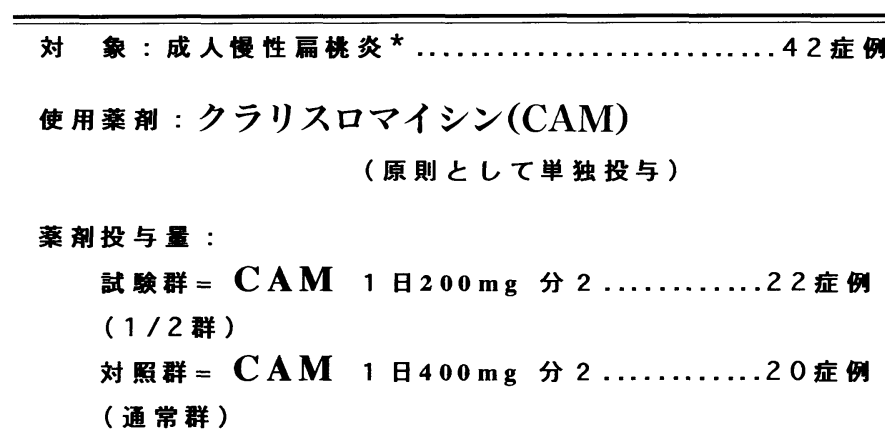

の 2 群に無作為に分けて投与

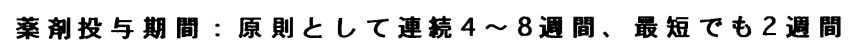

腺窝内耦菌検查: 投与前、投与後 2 週、投与終了後

（腹栓を認めた場合、可能な限り施行）

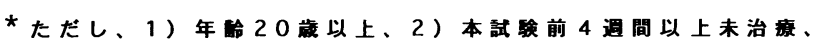

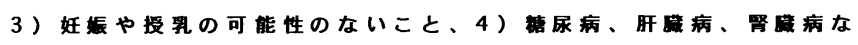

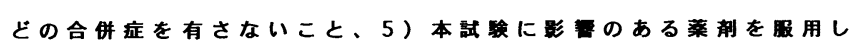

ていないこと、6) マクロライドアレルギーの蔇往のないこと、7)

習俱性扁楼炎の既往のないこと、8)精神障害その他て、主治医加

不䔔当と訊めた患者は除外する。 
栓は両側多発性，両側単発または一側多発性，一側単発 性, 前口蓋弓の挙上や圧迫で陰窩内に膿栓がわずかに確 認されたもの, を各々高度, 中等度, 軽度, ごく軽度と した. 各症例についての自覚症状，他覚所見の薬剤投与 終了時の改善度判定基準17) は表 2 の通りすべて正常化 したものを著明改善, ごく軽度まで改善したものを改善, 全く改善しなかったものを不変, 試験開始時よりも悪く なった場合を悪化とし, 改善と不変の間をやや改善とし た. 自覚症状，他覚所見の両者の改善度より各々の有効 性を著効 ( 3 点), 有効 ( 2 点), やや有効 ( 1 点), 無効 ( 0 点)の 4 段階で評価したのち, 表 3 のような総合判定基
準6)に従って全般改善度を判定し各々を統計学的に解析 した.データ解析にあたっては両側危険率を採用し, 有 意水準を $5 \%$ とした。すなわち, 各表中の有意差なし (N.S.) は両側危険率 $5 \%$ よ大であることを示す.

\section{結果}

\section{1. 患者背景}

有効症例数は合計42例で, 表 4 のように試験群 $(1 / 2$ 群)に打いては, 男性 4 例, 女性18例, 合計22例, 対照 群(通常群)に拈いては男性 5 例, 女性15例, 合計20例で あった. 年齢は, 試験群 $50.4 \pm 13.5$ 歳 (21〜76歳), 対照

表 2 改善度判定基準

\begin{tabular}{|c|c|c|c|c|c|}
\hline 投 & +++ & ++ & + & \pm & - \\
\hline+++ & 不変 & 整度改善 & 軽度改善 & 改 善 & 著明改善 \\
\hline++ & 悪化 & 不変 & 軽度改善 & 改 善 & 著明改善 \\
\hline+ & 悪化 & 覀化 & 不変 & 改 善 & 著明改善 \\
\hline
\end{tabular}

表 3 総合判定基準

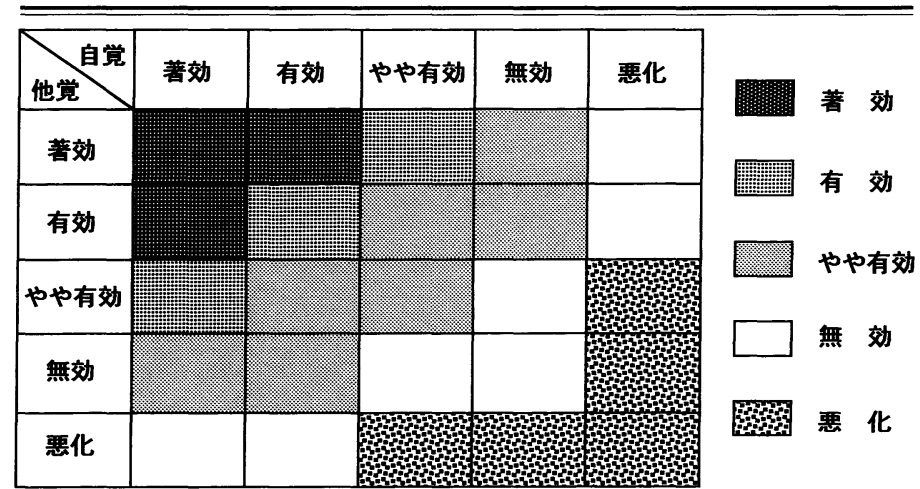

表 4 患者背景

\begin{tabular}{c|c|c|c|c}
\hline \hline & 男 : 女 & 年 齢 & 㥢病期間 (週) & 投薬期間(䓢) \\
\hline $\begin{array}{c}\text { CAM 200mg/日 } \\
(1 / 2 \text { 群) }\end{array}$ & $4: 18$ & $50.4 \pm 13.5$ & $18.8 \pm 38.8$ & $5.7 \pm 3.0$ \\
\hline $\begin{array}{c}\text { CAM 400mg/日 } \\
\text { (通常群) }\end{array}$ & $5: 15$ & $53.2 \pm 14.0$ & $13.1 \pm 14.4$ & $4.5 \pm 3.4$ \\
\hline 検 定 & 有意差なし & 有意差なし & 有意差なし & 有意差なし
\end{tabular}


群53.2土14.0歳 $(21 \sim 76$ 歳), 悩病期間は試験群 $18.8 \pm$ 38. 8週 ( $1 \sim 156$ 週), 対照群13.1土14.4週 ( $1 \sim 52$ 週), 投薬期間は試験群 $5.7 \pm 3.0$ 週 $(2 \sim 12$ 週 $)$, 対照群 $4.5 \pm$ 3.4 週 ( 2 13週), といずれに拈いても試験群・対照群 の両者間に統計学的有意差は認められなかった ( $\chi^{2}$ 検定).

\section{2 . 臨床効果}

臨床効果の最終結果は自覚症状・他覚所見・全般改善 度別に図 1 に揭げた。

1) 自覚症状

図1の上段に示したように自覚症状評価に拈いて試験 群 $(1 / 2$ 群) では, 有効以上 22 例中 16 例 $(73 \%)$, やや有効 を含めると 22 例中 17 例 $(77 \%)$, 対照群(通常群)では，有 効以上 20 例中 11 例 $(55 \%)$, やや有効を含めると 20 例中 12 例 $(60 \%)$ ，といら結果であった。 以上両群の自覚症状に 対する薬効の間には統計学的有意差を認めなかった (Mann-Whitney U-検定).

2 ）他覚所見

他覚所見評価においては図 1 の中段に示したように $1 / 2$ 群では, 有効以上 22 例中 16 例 $(73 \%)$, やや有効を含

1)自覚症状

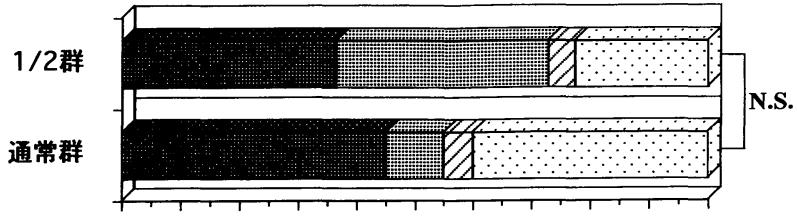

2) 他覚所見

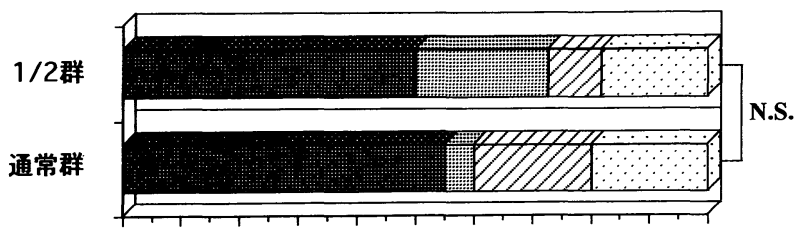

3）全 般 改 善 度

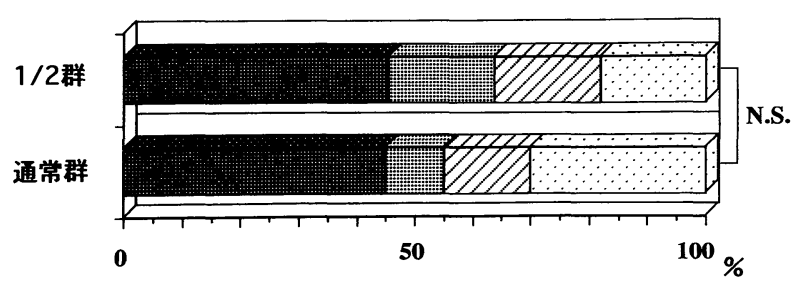

著効 囲 有効 曰やや有効 曰 無効

図 1 臨床効果
めると 22 例中 18 例 $(82 \%)$ で，発赤に対しては $100 \%$ ，膿 栓に対しては73\%が改善以上といら結果であった. 通常 群では, 有効以上20例中 12 例 (60\%), やや有効を含める と20例中 16 例 (80\%) で，発赤に対しては100\%，膿栓に 対しては $60 \%$ が改善以上であった. 以上両群の他覚所見 に対する薬効の間には統計学的有意差を認めなかった。 自覚症状スコアと他覚所見スコアとの相関性を調べると， $1 / 2$ 群で両スコア差が 0 点 $55 \%, 1$ 点 $27 \%, 2$ 点 $9 \%$, 3 点 $9 \%$, 通常群で両スコア差が 0 点 $60 \%, 1$ 点 $20 \%$, 2 点 $15 \%, 3$ 点 $5 \%$ であり両者の間にはいずれも高い相 関が認められた。

3 ）全般改善度

総合判定基準(表 3 ) 飞従って全般改善度（図 1 -下段） を判定すると，1/2 群では22例中14例 (64\%) が有効以上 で，22例中 18 例 (82\%) がやや有効以上といら結果であっ た. 一方通常群では，20例中 11 例(55\%)が有効以上， 20 例中 14 例 $(70 \%)$ がやや有効以上と判定された. 以上両群 の全般改善度に対する有効性には統計学的有意差を認め なかった。

3 . 陰窩内細菌培養検査

試験群と対照群の薬剤投与前後に扣ける検菌結果を有 効以上とやや有効以下に分けて検討すると 4 群の検菌結 果の間に大きな差は認められなかった．表 5 に試験群 $(1 / 2$ 群)の CAM 投与前後に拈ける検菌結果を有効以上 例とやや有効以下例に分けて示した．有効以上例・やや 有効以下例ともに $\alpha$-Streptococcus, Neisseria などの非病 原性常在菌が投与前・投与後ともに $1 \sim 2$ の例外を除い てすべて検出され，薬阂による常在細菌叢の擋乱は認め られなかった。一方病原性のある菌については有効以上 例 - やや有効以下例ともに, 薬凧投与後に拈いて Staphylococcus aureus, Streptococcus pyogenes なとは完全消失 したが, Haemophilus influenzae, Pseudomonas fluorescens, Enterococcus などが薬㶡投与後に 1 ～例におい て増加するなどの病原性細菌の消長傾向が見られた。 た近年社会問題化している MRSA（メチシリン耐性黄 色ブドウ球菌)の検出は両群・全経過を通じて皆無であ った。

\section{4. 副作用}

副作用は通常群では認められず， $1 / 2$ 群の 1 例 ( $5 \%$ ) に $5 \sim 6$ 週目に胃部不快感が認められ, 症状発現時点で 投与を中止し，すみやかに症状は消失した。また副作用 による試験の脱落例はなかった。 
表 5 陰窩内細菌検查結果

\begin{tabular}{|c|c|c|c|c|}
\hline 有効以上（投与前） & 13例 & $\rightarrow$ & （投与後） & 7例 \\
\hline$\alpha$-streptococcus & 12 & & Neisseria & 6 \\
\hline Neisseria & 11 & & $\alpha$-streptococcus & 5 \\
\hline S. aureus & 3 & & H. influenzae & 2 \\
\hline H. influenzae & 2 & & H. parainfuenzae & 1 \\
\hline S. pyogenes & 1 & & Ps. fluorescens & 1 \\
\hline S. epidermidis & 1 & & & \\
\hline S. macescens & 1 & & & \\
\hline Enterococcus & 1 & & & \\
\hline Candida & 1 & & & \\
\hline
\end{tabular}

\begin{tabular}{|c|c|c|c|c|}
\hline やや有効以下（投与前） & 8 例 & $\rightarrow$ & （投与後） & 6例 \\
\hline Neisseria & 8 & & Neisseria & 6 \\
\hline$\alpha$-streptococcus & 8 & & $\alpha$-streptococcus & 6 \\
\hline$r$-streptococcus & 3 & & Enterococcus & 2 \\
\hline S. aureus & 2 & & Ps. fluorecsens & 1 \\
\hline S. epidermidis & 1 & & H. influenzae & 1 \\
\hline Ps. fluorecsens & 1 & & & \\
\hline S. group $G$ & 1 & & & \\
\hline Gram-negative Rod & 1 & & & \\
\hline
\end{tabular}

\section{考案}

口蓋扁桃はワルダイエル咽頭輪の一部に属し, 上気道 の免疫防御機能を担っている. 慢性扁桃炎は咽喉頭異常 感を生ずる代表的疾患であるにもかかわらず，その診断

・治療および評価法などは未だ確立されたとは言い難い. 今回われわれは慢性扁桃炎の改善度の指標として, 自覚 症状に拈いては咽喉頭異常感に扣ける小池ら 15) の基準 と他覚所見に拈いては急性扁桃炎の判定基準16)17) の 4 段階(高度, 中等度, 軽度, なし) 評価にごく軽度を加え た 5 段階で評価した。これは慢性扁桃炎の自覚症状や他 覚所見が急性扁桃炎に比して軽微であり，軽度となしの 間に 1 段階加えた方がより的確に病状を反映すると考え たからである.この判定法は客観性・普遍性があり，自 覚症状スコアと他覚所見スコアの相関性も高く慢性扁桃 炎評価法の 1 つとしてれなりの意義を持つと考える. どのような評価法を選ぶにせよ，2本の舌圧子や口蓋弓 鈎などを用いて丹念に陰窩内膿栓を観察することが肝要 であることは言うまでもない。

今回, 慢性扁桃炎に対するクラリスロマイシン (CAM) $1 / 2$ 群と通常群の両群の薬効の間には統計学的有意差を
認めないものの自覚症状，他覚所見，総合判定いずれに 扣いても $1 / 2$ 群が通常群をやや上回り, 薬剤投与前後に 护ける陰窩内検菌では，両群ともに常在菌は除菌される ことがなく，一方で耐性菌の出現は少ないといら結果が 得られた．このことから CAM $1 / 2$ 量投与が慢性扁桃炎 に対して主にCAM の有する抗菌力以外の作用によって, 通常量投与に優るとも劣らない効果を発揮したことが推 察される。

びまん性汎細気管支炎，慢性副鼻腔炎などに対して行 なわれている14員環マクロライド少量長期投与の治療概 念は我が国で生まれ，育ったものであり，その抗菌力以 外のブースタ効果によって気道炎症を鎮静化するという ものであるが，われわれの行なった慢性扁桃炎に対する CAM 少量投与に拈いても，その根幹には共通の機序が 働いているものと思われる。そこで，これまでに報告さ れたびまん性汎細気管支炎，慢性副鼻腔炎などを中心と する研究を基に，慢性扁桃炎に対するクラリスロマイシ ン少量投与の有効性の機序を推論する.

14員環マクロライド少量長期投与の抗菌力以外の有効 性の主体は，宿主側因子と菌側因子に対する作用に大別 
され，現在までのところ宿主側因子に対する作用には主 に，1. サイトカインに対する作用18) 20)，2 . 炎症細 胞に対する作用221) 24), 3 . 粘膜線毛運動に対する作 用 ${ }^{25)}$ ， 4 . 気道分泌に対する作用 $\left.{ }^{25)} 27\right)$, などがあり,

菌側因子に対する作用には，1。アルギネートに対する 作用4)，2．バイオフィルムに対する作用3)，などが基 礎実験によって確認されている．またこれらの特性はマ クロライドすべてが持つわけではなく，側鎖の配置に依 存した14員環，15員環特有の性質であると考吕られてい $ろ^{4)}$.

口蓋扁桃は上気道粘膜免疫に打ける重要な 2 次りンパ 組織と考えられて扣り，局所免疫応答の誘導部位でもあ り実効部位でもある特異な臓器である。慢性扁桃炎は上 気道への細菌の侵入增殖といら感染因子と上気道局所の 感染防御能の低下といら免疫因子のバランスにより発症 し，遷延化する ${ }^{28)}$ と考兄られ，両因子の正常化が治療 の核となることは明らかである.

慢性下気道感染症においてはインターロイキン $1 \beta$ (IL-1 $\beta), \quad$ TNF $\gamma$ の増加に前駆されて IL-8 の過剩産生, 好中球エラスターゼの活性上昇18) といら悪循環が形成 されておりマクロライドが样々な刺激を受けて充進した

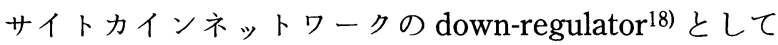
直接・間接的に炎症性免疫反応を正常化しているものと 考㝋られている. 副鼻腔炎に対するマクロライド療法で は $\mathrm{CD} 4+$ 細胞の減少によって $\mathrm{CD} 4 / 8$ 比を低下させるこ とによって，I 型アレルギー以外の炎症反応を抑制する 可能性が示されている20). 口腔内慢性炎症においては Th2 型サイトカインネットワークの破綻, 特に IL-4 の 減少を生じ，それによってマクロファージのアポトーシ スが生じない悪循環形成説が提唱されており 29 ), 分泌型 $\operatorname{Ig} \mathrm{A}^{28)}$ やアポトーシス30)31) の扁桃炎への影響が注目され る.

14員環マクロライドの免废賦活作用にはその他, 用量 依存的な活性醅素産生の抑制によるヒト好中球遊走能の 活性化 ${ }^{2224)}$, IL-4 産生に伴う単球/マクロファージの活 性化 ${ }^{19)}$ など炎症細胞・サイトカイン個々の変化を論ず る多くの報告があるが，難治性の慢性炎症巣に和いては サイトカインネットワーク全体の悪循環是正が14員環マ クロライドの作用の本質であることにおいては変わりが ないと思われる。

一方, マクロライドには正常な糖鎖構造をもつ粘液産 生を促すことにより粘液瀻毛輸送機能を改善した
り 2126)27), 用量依存的に気道上皮細胞の $\mathrm{Cl}^{-}$分泌に対す る抑制をすることで直接・間接的に水分分泌の抑制25)26) を行なっていることも示されている．われわれも喀痰分 泌については特に注意深く観察したが, 慢性扁桃炎患者 の自覚症状としての喀痰分泌もCAMによって抑制され ている印象であった。

最近では, 種々の感染の反復と炎症の遷延化にバイオ フィルム332) が関与寸ることが解かり，14員環マクロラ イドがバイオフィルムを破壊する作用3) も注目されてい る. またマクロライドが緑膿菌バイオフィルムの基質と なるアルギネート産生を抑制する4)ことも最近発表され た.これらの報告はびまん性汎細気管支炎関連であり, 現段階では口蓋扁桃にも本理論があてはまるのかどらか 不明であり, biofilm disease としての慢性扁桃炎 ${ }^{32}$ は今 後の課題となろう.

また，これらの研究のほとんどは薬剤投与量・投与期 間が臨床に㧊ける少量長期とは異なって扣り，マクロラ イドの少量長期投与の機序が完全解明されるには至って いない.

さて別の細菌学的見地, 特に菌種相互間の拮抗 - 共生 といら点から考光ると, 口腔常在細菌叢, 特に $\alpha$-streptococcus ${ }^{33334)}$ は病原菌発育抑制作用を有するとされ, 扁 桃に扣いては常在菌の増加と病原菌の減少といらバラン スの取れた菌の共生が望まれる．この点から常在細菌叢 を急激に擋乱するような強力な抗菌剤は不向きであり, 今回の結果からも明らかなように CAM 少量療法は他の 抗菌剤よりも合目的である。ただし，CAMのヒト扁桃 内濃度は CAM $150 \mathrm{mg}$ 投与 2 時間後において, 血清中 濃度の 10 倍強の $7.89 \mu \mathrm{g} / \mathrm{g}^{35)}$ といら優れた組織移行性が 指摘されているため, 定期的陰窩内細菌検査などで菌交 代現象 ${ }^{36)}$ や耐性菌出現 32335$)$ を監視すべきであろう.

さらにこれら以外にも考慮しなければならない因子と して M-5 などのマクロライド代謝産物131414の影響を挙 げることができる．特に抗菌剤の長期的効果を論じる場 合，その代謝産物が長期にわたって効果を発現すること も念頭に置き薬物を使用すべきであるとともに，この方 面の今後の更なる研究を待たねばならない。

今回の CAM 投与にあたっては, 予備段階で投薬後約 2 週で効果が出現し始め, $1 \sim 2$ 力月で有効性の評価が 扣おむね可能であるといら傾向を確認した上で， 4 〜 週で薬効を評価した。びまん性汎細気管支炎, 慢性副鼻 腔炎などでは投与期間が長い程，改善率が上昇してゆく 
とする報告4667) も多いが，マクロライドの慢性扁桃炎に 対する薬理作用に関して未知の部分の多い現時点に执い て，それ以上の長期投与効果については今後の課題とし たい。

$$
\text { まとめ }
$$

1 ）慢性扁桃炎に対する少量クラリスロマイシン (CAM) の臨床効果を, 試験群としてCAM $200 \mathrm{mg} /$ 日の 22例, 対照群としてCAM $400 \mathrm{mg}$ /日の 20 例を無作為的 に選択し， $4 \sim 8$ 週間投薬することによって比較検討し た.

2) CAM 投与終了後の全般改善度評価では, 試験群 は有効以上 $64 \%$ ，対照群は有効以上 $55 \%$ という結果であ った。

3) 自覚症状・他覚所見の改善度に沶いて, CAM 通 常量投与と $1 / 2$ 量投与との間に統計学的有意差を認めな かった.

4 ) 副作用は試験群の 1 例 ( $5 \%$ ) 飞おいて投薬後 5 〜 6 週目に発現したが，投薬中止後速やかに消失した。対 照群には副作用は認められなかった。

5 ) CAM 少量療法の薬効は, 免疫調節作用などを主 体とする14員環マクロライド独特の抗菌力以外の効果に 起因するものと推論した.

6 ）以上より, CAM 少量療法は咽喉頭異常感を訴兄 る慢性扁桃炎患者の治療に有用であると言える。

\section{参考文献}

1) 工藤翔二, 木村 七, 宮沢 博, 他 : びまん性沉細気管支 炎にたいするマクロライド系抗生剤少量長期間投与の臨床 効果. 日胸疾会誌 22 增: $254,1984$.

2 ) 二宮英昭, 市川洋一郎, 大泉耕太郎, 他 : びまん性沉細気 管支炎の気管支肺胞洗浄夜中ェラスターゼ活性についての 検討. 感染症学雑誌 $65: 672 \sim 680,1991$.

3 ）武田博明, 小林宏行, 明石 敏, 他: びまん性沉細気管支 炎に対するマクロライド作用の検討 一緑膿菌 biofilm に対 するクラリスロマインンの影響一. 感染症学雑誌 66 ： 1454 1461, 1992.

4) 小林宏行：びまん性汎細気管支炎に対するマクロライドの 作用機序. 化学療法 43: 96 101, 1995.

5 ) 高北晋一, 北村溥之, 大八木章博, 他 : 慢性副鼻腔炎と少 量エリスロマイシン療法. 耳鼻臨床 84 : 489 498, 1991.

6 ）菊池 茂, 洲崎春海, 野村恭也, 他: 副鼻腔炎とエリスロ マイシン少量長期投与. 耳鼻臨床 $84: 41 \sim 47,1991$.

7 ) 李 雅次, 渡部一雄, 䑪坂宗太郎, 他 : 慢性副鼻腔炎に対
するクラリスロマイシン少量長期投与療法. 耳展 $36: 657$ $\sim 662,1993$.

8 ）中村英生, 藤原 満, 中野雄一 : 慢性副鼻腔炎での CAM 少量長期投与の効果. 耳鼻臨床 $88: 1095 \sim 1099,1995$.

9 ）飯野ゆき子, 杉田公一, 鳥山 稔, 他 : 出性中耳炎に対 するエリスロマイシン少量長期投与療法の効果. 日耳鼻 $94: 1537,1991$.

10) Iino $Y$, Kudo $K$, Toriyama $M$, et al : Erythromycin therapy for otitis media with effusion in sinobronchial syndrome. Arch Otolaryngol Head Neck Surg $119: 648 \sim 651$, 1993.

11）藤田明彦, 高北晋一, 高橋晴雄, 他 : 難治性渗出性中耳炎 と CAM 少量長期投与. 耳鼻臨床 87 : 1287 1291, 1994.

12）三笠桂一，澤木政好，喜多英二，他：原発性肺癌に対寸る clarithromycin 長期投与の試み一Biological response modifier としての可能性一. Chemotherapy $42: 1293 \sim 1298$, 1994.

13）諏訪俊男, 浦野英俊, 児玉智子, 他 : TE-031 の体内動態(第 8 報）ヒトに扣ける吸収打よび排泄(bioassay法). Chemotherapy $36: 921 \sim 932,1988$.

14）長手尊俊, 明石 敏, 大村貞文, 他 : TE-031のヒト主要 代謝物 M-5 の抗菌作用について. Chemotherapy 36 補 3 : 156 169, 1988.

15）小池靖夫, 石谷保夫, 中村克彦, 他 : 咽喉頭異常感の数量 化について. 耳鼻臨床 補23：46〜 50, 1988.

16）佐々木亭, 杉森久一, 佐々木幸弘, 他: 耳鼻咽喉科領域感 染症に対する TE-031 の臨床評価. 耳鼻 34 ：1535～1553, 1988.

17）河村正三, 高坂知節, 馬場駿吉, 他 : 急性陰窩性扁桃炎に 対する TE-031 と Josamycin の薬効比較試験. 耳鼻 35 : 134〜151, 1989.

18）大石和徳: 慢性下気道感染症におけるインターロイキン 8 (IL-8) の役割とエリスロマイシンの IL-8 産生抑制効果. 化 学療法の領域 $10: 1299 \sim 1304,1994$.

19) Kita E, Sawaki M, Mikasa K, et al : Alterations of host response by a long-term treatment of roxithromycin. J Antimicrob Chemother $32: 285 \sim 294,1993$.

20）飯野ゆき子, 宮澤哲夫：マクロライド療法の有効性と副鼻 腔粘膜病理. 耳展 38 補 $3: 269 \sim 273,1995$.

21）大山 勝, 花牟礼豊, 上野員義, 他 : 副鼻腔気管支症候群 一最近の話題を中心に一. 耳鼻臨床 $88: 273 \sim 284,1995$.

22）門田淳一, 山口恵三, 原 耕平, 他 : 難治性下気道感染症 に打けるェリスロマイシンの好中球機能に及ぼす影響 — 緑膿菌への作用と気管支肺胞洗浄液の検討一. 感染症学雑 誌 $65: 277 \sim 285,1991$.

23) Perry DK, Hand WL, Lambeth JD, et al : Role of phospholipase D-derived diradylglycerol in the activation of the human neutrophil respiratory burst oxidase. Inhibi- 
tion by phosphatidic acid phosphohydrolase inhibitors. J Immunol $149: 2749 \sim 2758,1992$.

24) Anderson R : Erythromycin and roxithromycin potentiate human neutrophil locomotion in vitro by inhibition of leukoattractant-activated superoxide generation and autooxidation. J Infectious Dis 159 : 966 973, 1989.

25）玉置 疜：マクロライドと気道分泌.化学療法の領域 10 : 1293 1297, 1994.

26) Suez D and Szefler SJ : Excessive accumulation of mucus in children with asthma; A potential role for erythromycin? A case discussion. J Allergy Clin Immunol 77 : 330 334, 1986.

27) Goswami SK, Kivity S and Marom $Z$ : Erythromycin inhibits respiratory glycoconjugate secretion from human airways in vitro. Am Rev Respir Dis $141: 72 \sim 78,1990$.

28）保富宗城, 藤原啓次, 山中 昇, 他 : 慢性副鼻腔炎に批 る上気道粘膜免疫 一扁桃扣よびアデノイドに打ける免疫 担当細胞の変化一. 耳展 38 補 $3: 244 \sim 250,1995$.

29）清野 宏: 口空・咽頭の免疫機構：サイトカインによる粘 膜免疫と炎症の誘導. 口咽科 $8: 1,1995$.

30) Fujimori M, Ichikawa G, Shirai $T$, et al : Identification of apoptotic cells in human palate tonsils. Immunobiology in
Otorhinolaryngology. Progress in a Decade (ed by Mogi G, Veldmann JE and Kawauchi H). pp 561 562, Kugler, Amsterdam/New York, 1994.

31）川端五十鈴, 田部浩生：ヒト扁桃肧中心での apoptosis 一tingible body macrophage を中心に一. 耳鼻臨床 88 : 1489 1497, 1995.

32）小林武宏：扁桃炎の抗菌化学療法. 口咽科 $7: 255 \sim 263$, 1995.

33) 岸本 厚, 森疜, 西村忠郎, 他 : 扁桃炎の臨床細菌学. 口咽科 $7: 265 \sim 272,1995$.

34）藤森 功, 山田俊彦 : 扁桃炎症例に拈ける抑制性 $\alpha$-レンサ 球菌の検出状況. 日耳鼻 $95: 400 \sim 408,1992$.

35）宮崎康博, 花军礼豊, 大山 勝, 他 : 耳鼻咽喉科領域感染 症に対する TE-031 の基礎的 - 臨床的研究. Chemotherapy 36 補 $3: 926 \sim 934,1988$.

36）木村貴昭, 保冨宗城, 山中 昇, 他: CAM 療法に括ける 検出菌の変化. 耳鼻臨床 $89: 39 \sim 44,1996$.

$\left(\begin{array}{l}\text { 原稿受付: 平成 } 8 \text { 年 } 2 \text { 月 } 20 \text { 日 } \\ \text { 原稿採択 : 平成 } 8 \text { 年 } 3 \text { 月 } 1 \text { 日 } \\ \text { 別刷請求先 : 三沢逸人 } \\ \boldsymbol{\mathbf { T }} 492 \text { 稲沢市御供所町 } 1-1 \\ \text { 稲沢市民病院耳鼻咽喉科 }\end{array}\right)$

